\title{
THE EFFECTS OF PERSONALITY, SELF-EFFICACY, AND LOCUS OF CONTROL ON THE SUCCESS OF JAVANESE FEMALE MERCHANTS IN SURABAYA
}

\author{
Nur Laily*11 and Dewi Urip Wahyuni*) \\ *) Sekolah Tinggi Ilmu Ekonomi Indonesia (STIESIA) Surabaya \\ Jl. Menur Pumpungan No 30 . Surabaya
}

\begin{abstract}
The study aimed to examine the effect of personality on self-efficacy, locus of control, and the success of Javanese female merchants in the modern market, Surabaya, Indonesia. Questionnaire was used as a research instrument in this study. This study involved 100 Javanese female merchants as respondents. The samples were collected through a non-probability sampling technique. The data were analyzed based on Partial Least Square analysis using Smart PLS software. The findings of this study indicated that all five research hypotheses proposed in this study were accepted. First, personality affected self-efficacy. Second, personality affected the locus of control. Third, personality affected the success of the Javanese female merchants. Fourth, self-efficacy affected the success of the Javanese female merchants and the locus of control affected the success of Javanese female merchants in the modern market, Surabaya, Indonesia.
\end{abstract}

Keywords: personality, self-efficacy, locus of control, Success, Javanese female merchants

\begin{abstract}
Abstrak: Penelitian ini bertujuan untuk mengetahui pengaruh kepribadian terhadap self-efficacy, locus of control, dan keberhasilan wanita pedagang etnis Jawa di pusat perbelanjaan Jembatan Merah Plaza Surabaya. Kuesioner digunakan sebagai instrumen penelitian dalam penelitian ini. Sampel yang diambil sebanyak 100 responden wanita pedagang etnis Jawa. Pengambilan sampel menggunakan teknik non-probability sampling. Penelitian ini menggunakan analisis Partial least Square (PLS) dengan menggunakan Software SmartPLS. Penelitian ini menunjukkan bahwa kepribadian berpengaruh terhadap self-efficacy, locus of control, dan keberhasilan wanita pedagang etnis Jawa di pusat perbelanjaan Jembatan Merah Plaza Surabaya. Hasil pengujian pengaruh mediasi dengan menggunakan rumus Sobel membuktikan kepribadian berpengaruh tidak langsung terhadap Keberhasilan melalui Self efficacy wanita pedagang etnis Jawa, dan kepribadian berpengaruh tidak langsung terhadap Keberhasilan melalui Locus of Control wanita pedagang etnis Jawa.
\end{abstract}

Kata kunci: kepribadian, self-efficacy, locus of control, keberhasilan, wanita pedagang etnis Jawa

\footnotetext{
${ }^{1}$ Corresponding author:

Email: nurlaily@stiesia.ac.id
} 


\section{INTRODUCTION}

Every woman has a different character. Some do not work due to their housewife role, but some work because they have to support their family. According to Laily and Wahyuni (2018), succesful female entrepreneurs were not created by chance and great intentions within the success itself. Many women choose to work as merchants, so they needto work harder. They choose that job because it does not need high education. Being a merchant can also be a pastime for women as they may communicate and interact with their fellow merchants while waiting for the customers.

Women's involvement in trade business (either qualitatively or quantitatively) has become an interesting topic to study. Trade business in which the women interested in has its own specific characteristics that differ from other forms of businesses. Trade business is tough, competitive, challenging, highrisk, and speculative. According to Department of Agricultural (1995) in Sucipto et al. (2015), small, medium, or large businesses are on the principles of mutual needs, strength, and profits. Therefore, only individuals with a great personality can survive in this business (Setyorini, 2002). Sulistyo and Adiatma (2011) in Sucipto et al. (2015) revealed that the ability of small enterprises to become independent could be improved through capital and training supports, i.e. by enhancing or improving the human resources to be professional and skillful in supporting the marketing and business continuity in the future. The female merchants consider the risks they are going to take and bravely take the risks. They are eager to face the challenges because they love challenges and believe that they are able to overcome the challenges and succeed. The success of a female merchant is inseparable from her personality, self-efficacy, and locus of control. Hermawan et al. (2016) stated that a person with an interest in starting a business will have the readiness and better progress in the effort to run than someone with no interest in starting a business.

Personality must be owned by every woman who will do an entrepreneurship. Based on Brandstatter (2011), personality traits of entrepreneurs have previously been linked to success and sustainability of entrepreneurial ventures. Personality refered to a series of relatively stable characteristics that were inherent on an individual and affect the way the individual reacts and interacts with his/her surroundings (Robbins and Judge, 2010).
Self-efficacy is a belief that is owned by someone so that the business becomes succesful and run well. Bandura in Hermawan et al. (2016) stated that self-efficacy was one of the potentials that exists in the human cognitive factors, self-efficacy was a major effect on human behavior. High self-efficacy owned by an individual makes him/her love challenges. Together with high endurance, self-efficacy drives an individual to achieve his/her goals. Individuals with high self-efficacy tend to overcome challenges easily. They do not hesitate because they believe in their capability.

Locus of control is a belief that success and failure its own her responsibility from the result of her business. According to Baharuddin (2015), locus of control was one of the variables of personality which was defined as the individual's belief in the ability to control his/her own destiny. Someone who has a locus of control will have self- confidence to succeed. Based on Hermawan et al. (2016), locus of control was a personality variable associated with general expectations of a person whether someone will be able to control events in life or not.

As merchants, women are more flexible. The success they achieved cannot be separated from their excellent personality as Javanese: tenacity, patience, painstaking, self-efficacy, and their locus of control in facing business challenges (Suryana, 2001; Donatelle, 2011; Laily and Wahyuni, 2018) . In Javanese culture, women are positioned as konco wingking (subordinates of men or devoted followers of their husbands). Women and men do not have equal position. Women are supposed to carry out their pre-destined duty to take care of their husbands and children and doing household chores. Recently, Javanese women started to do other activities, including getting involved in trade business as merchant though they were still tied to Javanese cultural value, namely to be obedient wives and be respectful to their husbands (Agustina, 2014).

Based on the phenomenon explained above, the writer found the effects of personality, self-efficacy, and locus of control on the success achieved by Javanese female merchants was interesting to analyze since their success and existence as female merchants were inseparable from their culture. The social construction expects these women to become individuals inseparable from their domestic roles. On the other hand, the urging financial needs force them to be more active in supporting the funding in their family. Based on Le and Eni (2013), 
self efficacy influenced business success. Hermawan et al. (2016) stated that there was an effect of internal locus of control on the interest in entrepreneurship.

The purposes of this study were to analyze the influence of personality, self-efficacy, and locus of control on the success achieved by Javanese female merchants and to examine the indirect effect of female merchant's personality on her success through self-efficacy and locus of control.

The scope of this study is that it was conducted on Javanese women involved in trade and become succesful due to hard work and patience. Besides, they also had personality, self-efficacy, and locus of control so they could face the challenges. Self-efficacy could lead them to be succesfull.

\section{METHODS}

This study was an explanatory research. This data used were primary and secondary data. The primary data were collected from the female merchants in the modern market, especially Jembatan Merah Plaza, Surabaya. Other related data were secondary data. The population of this study were all the female merchants in Jembatan Merah Plaza Surabaya, which amounted to 500 merchants. The sample of this study were chosen based on non-probability sampling technique. Based on the technique, the sample of this study consisted of 100 respondents.

The data used in this study were collected using questionnaire. The collected data were analyzed using Partial Least Square (PLS) approach. PLS is a type of Structural Equation Modeling (SEM) equation that is based on components (variants). Ghozali (2006) explained that PLS is an alternative approach that shifts SEM approach from covariant-based to variant- based. Estimation of the parameters obtained from PLS approach can be classified into three categories, namely: weight estimate (used to formulate the score of latent variables, path estimate (connecting the latent variables and connecting latent variables to their indicators), and means and location of the parameter (the value of regression constants) for each indicator and latent variable. In order to formulate these three estimates, PLS applies three phases of iteration. Each phase of iteration results in one estimate. Conceptual framework in Figure 1.

\section{RESULTS}

\section{Outer Model}

Convergent validity of the estimation model with reflective indicators is assessed based on the correlation among component scores estimated by PLS software. An individual reflective is considered valid if the indicator shows correlation to the estimated construct with loading factor more than 0.70. However, Chin (2008) as cited in Ghozali (2006) stated that loading factors $0.5-0.6$ are considered valid in initial researches aimed to develop a scale. In this study, the applied validity threshold for the loading factors was 0.60. Figure 2 shows the the output of PLS (the model's path diagram) processed using Smart PLS software.

The analysis using Smart PLS software indicated that the loading factors of the correlations among the variables and indicators were statistically significant and valid in measuring each sub-indicators with the loading factor $\geq 0.6$ and t-statistic value $>1.96$ at the significance level $(\alpha)$ of 0.05 or $5 \%$. This result meant that all the indicators were statistically significant and valid in measuring the sub-indicators. The results of loading factors can be seen in Table 1 .

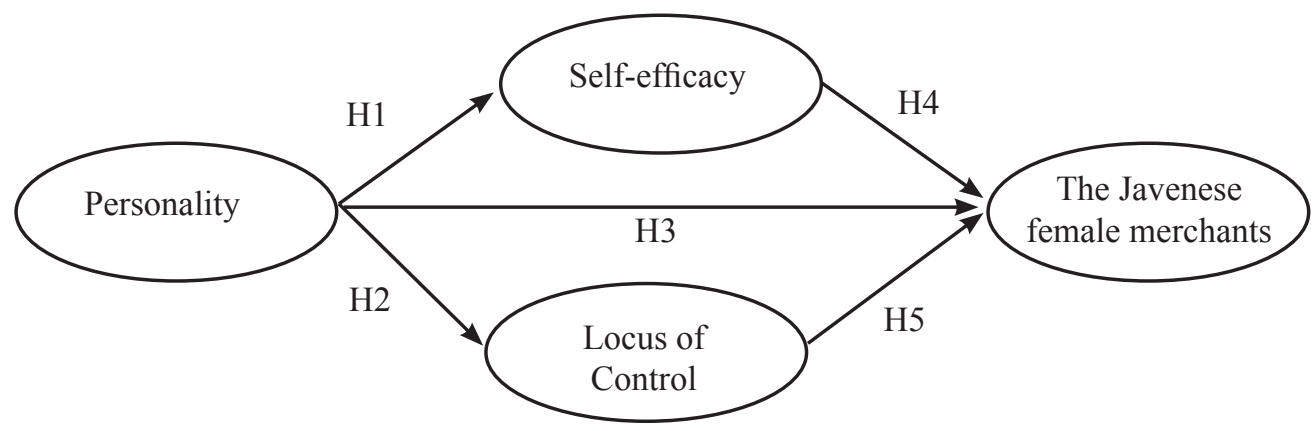

Figure 1. Reseach framework 


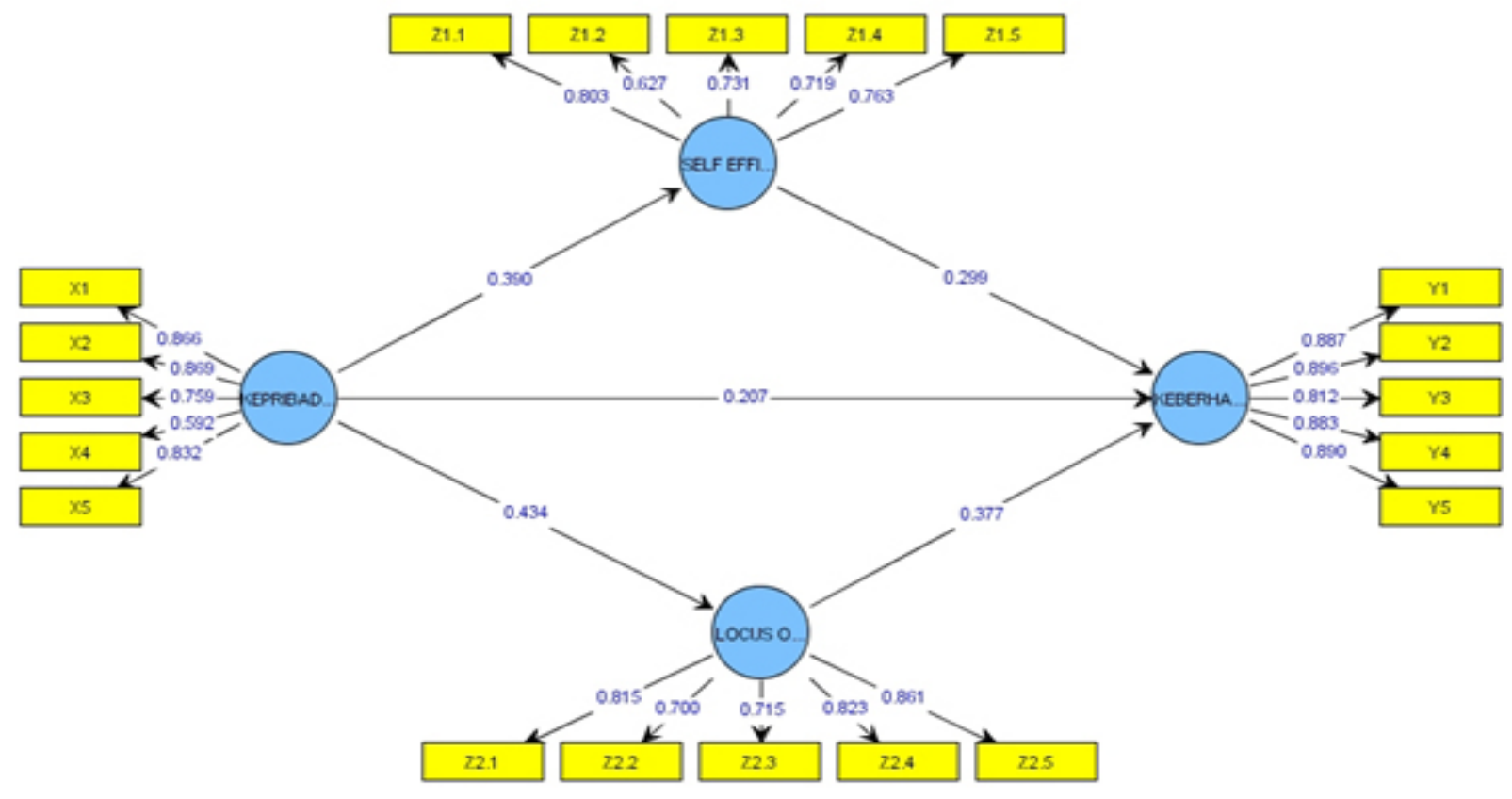

Figure 2. Model's path diagram

Table 1. Loading factors

\begin{tabular}{lcccc}
\hline & $\begin{array}{c}\text { Original Sample } \\
\text { Estimate }\end{array}$ & Mean of Subsamples & Standard Deviation & t-Statistic \\
\hline PERSONALITY (X) & & & & \\
X1 & 0.866 & 0.863 & 0.044 & 19.503 \\
X2 & 0.869 & 0.859 & 0.047 & 18.670 \\
X3 & 0.759 & 0.747 & 0.073 & 10.349 \\
X4 & 0.592 & 0.572 & 0.141 & 4.195 \\
X5 & 0.832 & 0.837 & 0.062 & 13.488 \\
SELF-EFFICACY (Z1) & & & & \\
Z1.1 & 0.803 & 0.810 & 0.056 & 14.434 \\
Z1.2 & 0.627 & 0.622 & 0.123 & 5.114 \\
Z1.3 & 0.731 & 0.727 & 0.101 & 7.240 \\
Z1.4 & 0.719 & 0.706 & 0.116 & 6.209 \\
Z1.5 & 0.753 & 0.088 & \\
LOCUS OF CONTROL (Z2) & & & & 16.111 \\
Z2.1 & 0.815 & 0.817 & 0.051 & 7.105 \\
Z2.2 & 0.700 & 0.704 & 0.099 & 7.247 \\
Z2.3 & 0.713 & 0.099 & 16.562 \\
Z2.4 & 0.715 & 0.818 & 0.050 & 16.720 \\
Z2.5 & 0.823 & 0.862 & 0.051 & 28.269 \\
SUCCESS OF A FEMALE MERCHANT (Y) & & & 24.540 \\
Y1 & 0.887 & 0.885 & 0.031 & 15.957 \\
Y2 & 0.896 & 0.897 & 0.037 & 27.033 \\
Y3 & 0.812 & 0.813 & 0.051 & \\
Y4 & 0.883 & 0.879 & 0.029 & \\
Y5 & 0.890 & & 0.033 &
\end{tabular}


Table 1 shows that the indicator that gives the highest contribution to personality was X1 (openness to experience) with the loading factor of 0.866 . The highest contributor for self-efficacy was Z1.1 (process of business operation) with the loading factor of 0.803 ; while the highest contributor for locus of control was Z2.5 indicator (leadership) with the loading factor of 0.861 . The biggest contributor for female merchant success was Y5 (ability to balance professional responsibilities and responsibilities for the family).

Validity and reliability criterion can also be measured from reliability value of a construct and Average Variance Extracted (AVE) index of each construct. A construct is considered reliable if its reliability value is higher than or equals to 0.70 and its AVE index is not lower than 0.50 . The value of Composite Reliability and AVE indexes of each variable are presented in Table 2.

In Table 2, personality, self-efficacy, locus of control, and success of a female merchant variables have AVE index higher than 0.5 and Composite Reliability value higher than 0.7. Based on these results, all of the indicators used in these variables were reliable and significant in measuring the constructs.

\section{Inner Model}

Examination on an inner model (structural model) aims to find out the correlations among the constructs, significance value, and R-square index of a research model. The structural model is evaluated by using the R-square index of t-test dependent constructs and significance coefficients of structural path parameters. PLS analysis on an estimation model starts with examining the R-square indexes for each latent dependent variables. Table 3 presents the R-square estimation for each variable.

The results (as presented in Table 3) showed that the R-square index for self-efficacy variable was 0.152 , which meant that self-efficacy variable can be explained by personality construct variable as much as $0.152(15.2 \%)$. The R-square index for the locus of control variable was 0.189 , which meant that the locus of control variable can be explained by oersonality construct variable as much as 0.189 (18.9\%). The $\mathrm{R}$-square index for the success of a female merchant variable was 0.532 , which meant that $53.2 \%$ of the success of female merchant was determined by personality, self-efficacy, and locus of control while the rest $(46.8 \%)$ was determined by other variables that were not examined in this study.

Hypotheses results were seen through t-statistic. The result is accepted if t-statistic $>1,96$ (two-tailed). The loading factors of the correlations among the variables and indicators were statistically significant and valid in measuring each sub-indicators with loading factor $\geq 0.6$ and $t$-statistic value $>1.96$ at the significance level $(\alpha)$ of 0.05 or $5 \%$. Table 4 presents the correlations among constructs and t-statistic.

Table 2 Composite reliability and Average Variance Extracted (AVE) Index

\begin{tabular}{lcc}
\hline & Composite Reliability & Average Variance Extracted (AVE) \\
\hline Personality (x) & 0.891 & 0.624 \\
Self-efficacy (z1) & 0.851 & 0.534 \\
Locus of control (z2) & 0.889 & 0.617 \\
Success of a female merchant (y) & 0.942 & 0.764 \\
\hline
\end{tabular}

Table 3. R-Square index for each variables

\begin{tabular}{lc}
\hline & R-square \\
\hline Personality (x) & - \\
Self-efficacy (z1) & 0.152 \\
Locus of control (z2) & 0.189 \\
Success of a female merchant (y) & 0.532 \\
\hline
\end{tabular}


Table 4. Correlations among constructs and t-statistic

\begin{tabular}{lcccc}
\hline & $\begin{array}{c}\text { Original sample } \\
\text { estimate }\end{array}$ & $\begin{array}{c}\text { Mean of } \\
\text { subsamples }\end{array}$ & $\begin{array}{c}\text { Standard } \\
\text { deviation }\end{array}$ & t-Statistic \\
\hline Personality $(\mathrm{X}) \rightarrow$ Self efficacy $(\mathrm{Z1})$ & 0.390 & 0.424 & 0.108 & 3.616 \\
Personality $(\mathrm{X}) \rightarrow$ Locus of control $(\mathrm{Z} 2)$ & 0.434 & 0.447 & 0.101 & 4.316 \\
Personality $(\mathrm{X}) \rightarrow$ Success of a female merchant $(\mathrm{Y})$ & 0.207 & 0.201 & 0.092 & 2.266 \\
Self efficacy $(\mathrm{Z} 1) \rightarrow$ Success of a female merchant $(\mathrm{Y})$ & 0.299 & 0.317 & 0.093 & 3.203 \\
Locus of control $(\mathrm{Z} 2) \rightarrow$ Success of a female merchant $(\mathrm{Y})$ & 0.377 & 0.376 & 0.100 & 3.787 \\
\hline
\end{tabular}

As shown in Table 4, the first hypothesis (H1), stating that personality affects the self-efficacy of Javanese female merchants, showed the path correlation coefficient of 0.390 with a t-statistic value of 3.616 (higher than t-table value 1.960). This result meant that personality (X) affected self-efficacy (Z1), and the first hypothesis was accepted. The second hypothesis (H2), stating that personality affects the Javanese female merchants' locus of control, showed the path correlation coefficient of 0.434 with a t-statistic value of 4.316 (higher than t-table value 1.960). This result meant that personality $(\mathrm{X})$ affected locus of control (Z2), and the second hypothesis was accepted. The third hypothesis (H3), stating that personality affects the success of Javanese female merchants, showed the path correlation coefficient of 0.207 with a t-statistic value of 2.266 (higher than $\mathrm{t}$-table value 1.960). This result meant that personality $(\mathrm{X})$ affected the success of Javanese female merchants (Y), and the third hypothesis was accepted. The fourth hypothesis (H4), stating that self-efficacy affects the success of Javanese female merchants, showed the path correlation coefficient of 0.299 with a t-statistic value of 3.202 (higher than t-table value 1.960). This result meant that self-efficacy (Z1) affected the success of Javanese female merchants $(\mathrm{Y})$, and the fourth hypothesis was accepted. The fifth hypothesis (H5), stating that locus of control affects the success of Javanese female merchants, showed the path correlation coefficient of 0.377 with a t-statistic value 3.787 (higher than $t$-table value 1.960). This result meant that locus of control (Z2) affected the success of Javanese female merchants (Y), and the fifth hypothesis was accepted.

One of Javanese women personality traits, openness to others and their past experiences has made Javanese women to be hardworking, eager to face new challenges, and innovative individuals. This unique personality trait of Javanese women supports self-efficacy of the female merchants in their business. Javanese female merchants are known for their tenacity and hard work.
In Javanese traditional wet markets in which most of the merchants are women, the merchants come to the market before the sun rises. Similar attitude is also found on the Javanese female merchants in the modern market Surabaya.

The Javanese female merchants with their excellent personality traits (openness, hardworking, and tenacity) and high self-efficacy can successfully operate their business. Self-efficacy of the Javanese female merchants determines their success. This means that these Javanese female merchants are confident in their capability in carrying out business operation. The Javanese female merchants with high self-efficacy believe that their skills and competence facilitate them in achieving their business targets.

The confidence in their own skills and competence are the most important provision in achieving business success. For a merchant, self-efficacy strongly correlates with the process of business operation, namely ability to understand business operation and the ability to perform his/her professional responsibilities. This finding confirms the findings of previous research conducted by Hartman (2006) stating that personality generated self-efficacy. The finding of this study also supports the results of a study carried out by Hermann (2005). This finding proves a theory proposed by Kreitner and Kinicky (2005) stating that individuals with internal locus of control perceived the achievements they made were determined by their activities while individuals with external locus of control believe that the success they made was controlled by outer power.

Several findings of this study need further intervention by decision-makers (stakeholders) and academicians. Most of Javanese female merchants in the modern market Surabaya have never received entrepreneurship training before. Their success as female merchants depends on their past experiences and what was taught by their parents. Most of these female merchants are 
young. Entrepreneurship training for the Javanese female merchants helps them to become independent businesswomen.

\section{Managerial Implication}

Javanese female merchants' personality affected their success through locus of control. The success achieved by the Javanese female merchants depends on their personality and their ability in controlling their emotions. Javanese women believe that the success (or failure) they achieved in their activities depends on their self-control and control over their surroundings. This finding showed that the Javanese female merchants had the potential to determine their own life. They believe that they can face the challenges and threats they got from their surroundings. These female merchants confidently attempts to solve every problem that happened in their business, including conflicts with fellow merchants.

\section{CONCLUSIONS AND RECOMMENDATIONS}

\section{Conclusions}

Personality affected self-efficacy, locus of control, and the success of Javanese female merchants. The findings of this study also proved that self-efficacy and locus of control determined the success of Javanese female merchants in their business. The Javanese female merchants with their excellent personality traits (openness, hardworking, and tenacity) and high selfefficacy can successfully operate their business. The government has to give motivation to the Javanese female merchants in Jembatan Merah Plaza through training. Training help them to become successful women and stand in their feet. They also help their families in order to survive in their life.

\section{Recommendations}

This research focused on women's involvement in the trade business. The success of a female merchant is inseparable from her personality, self-efficacy, and locus of control. In the future, we hope that all of the women who run a business can be successful as business women, and they support their family in order to survive their life.

\section{REFERENCES}

Agustina TS. 2014. Mengungkap perilaku inovatif 3 etnis wanita pedagang di Surabaya. Jurnal Manajemen Teori dan Terapan 7(1): 23-37.

Bandura A. 1997. Self Efficacy. The Exercise of Control. New York: W.H. Freedman and Company.

Baharuddin M. 2015. Pengaruh locus of control dan sikap berwirausaha terhadap intensiberwirausaha melalui kreativitas. Jurnal Administrasi Publik 2(2).

Brandstatter H. 2011. Personality aspect of entrepreneurship: a look at five meta-analyses. Personality and Individual Aspect Differences 51(3): 222-230. http://doi.org/10.1016/j. paid.2010.07.007

Donatelle R. 2011. Health: The basics (Green ed.). San Francisco: Pearson Benjamin Cummings.

Ghozali I. 2006. Aplikasi Analisis Multivariate dengan Program SPSS. Semarang: Badan penerbit Universitas Diponegoro.

Hartman R. 2006, The five factor modeland career self-efficacy: general and domain-specific relationship [dissertation]. Athens: The Ohio State University.

Hermann KS. 2005, The influence of socialself-efficacy, self-esteem, and personality differences on lonelinessand depression [dissertation]. Athens: The Ohio StateUniversity.

Hermawan RW, Budi ES, Wening PR. 2016. The effect of entrepreneurial self-efficacyand locus of controlon entrepreneurshipinterest through entrepreneurship literacy. OSR Journal of Business and Management (IOSR-JBM) 18(2): 141-148.

Kreitner R, Kinicky. 2005. Organizational Behavior. McGraw-Hill Companies

Laily N, Wahyuni DU. 2018. The key success female entrepreneurs batik jonegoro in Indonesia. International Journal of Business Administration 9(2): 67-79. https://doi.org/10.5430/ijba. v9n2p67.

Le M, Eni M. 2013. Pengaruh efikasi diri dan motivasi terhadap keberhasilan usaha pada pemilik toko pakaian di pusat grosir metro Tanah Abang, Jakarta. Jurnal Manajemen 13(1).

Robbins SP, Judge TA. 2009. Organizational Behaviour. Pearson education, New York.

Setyorini TD. 2002. Pengaruh Sikap terhadap Peran Tradisional - Non Tradisional Wanita dan Locus of Control terhadap Motivasi Berprestasi pada 
Wanita Pedagang Batik Etnis Jawa, Cina dan Arab di Pasar Klewer Kotamadya Surakarta. [thesis]. Jakarta : Program Pasca Sarjana Fakultas Psikologi UI.

Sucipto E, Rina O, Rizal. 2015. The effects of Partnership and entrepreneurship towards business performance of oyster mushroom. Indonesian Journal of Business and Entrepreneurship 1(1):32-41. https://doi. org/10.17358/IJBE.1.1.32.

Suryana. 2001. Kewirausahaan. Jakarta: Penerbit Salemba Empat. 